\title{
WALTER ANDERSON'S LETTERS TO JOAN AMADES: A STUDY OF THE COLLABORATION BETWEEN TWO CONTEMPORARY FOLKLORISTS
}

\author{
Carme Oriol
}

\begin{abstract}
Between 1953 and 1958, Walter Anderson and Joan Amades maintained a frequent correspondence, in which they discussed issues related to the study of folklore. Of these letters, only those written by Walter Anderson - a total of 31 - have been preserved. This article examines the contents of those letters and, consequently, the nature of the collaboration between the two folklorists. In addition to some biographical details, the letters provide first-hand information about the work the folklorists were doing, the publications they exchanged, their participation in folklorist associations and international conferences, etc. However, the letters show, above all, the extent to which Anderson acted as Amades's mentor, especially on issues related to the cataloguing of Catalan folktales a project which was still unfinished when Joan Amades died in 1959, followed by Walter Anderson in 1962, and which was not completed until more recently.
\end{abstract}

Keywords: collected letters, folklore, folktale, history of folklore studies, historical-geographical method, Joan Amades, Walter Anderson

On the 125th anniversary of the birth of Joan Amades

\section{INTRODUCTION}

Walter Anderson was born in Minsk on 10 October 1885 and died in Kiel on 23 August 1962. Anderson's family background meant that he was likely to receive a university education. He studied classical philology at the University of Kazan and later continued his studies at the Department of Germanic and Romance philology at the University of St. Petersburg. Initially his research focused on folktales in classical literature; however, over time his attention increasingly turned towards the study of folklore in its own right. Between 1920 and 1939, he occupied the first Chair of Estonian and Comparative Folklore at the University of Tartu. Between 1940 and 1945, he was professor of folklore at the University of Königsberg and, between 1945 and 1953, at the Univer- 
sity of Kiel, where he remained as a professor emeritus until 1962. In 1950 he spent several months as a visiting scholar at the University of Bloomington (Indiana) along with Professor Stith Thompson (1885-1976). He was renowned for his knowledge of the historic-geographic method, an area in which he made several important theoretical contributions, some of which were not without controversy, such as his Law of Self-Correction and the concept of "Normalform" (Seljamaa 2005: 154). His formidable gift for languages (he had a command of more than 40, in addition to several dialects) enabled him to study folklore from the perspective of the historic-geographic method, which he regarded as a specific scientific method for studying folklore. He made innovative contributions to the study of folklore, such as the experiments he conducted to demonstrate the validity of the Law of Self-Correction (Anderson 1951, 1956), and his research into aspects of contemporary folklore such as chain letters (Anderson 1937) and rumours (Anderson 1925-1926, 1960). His study of rumours titled Die Marspanik in Estland 1921 (Anderson 1925-1926) was one of the first to examine this phenomenon as an element of folklore (Kalmre 2013: 18).

Joan Amades was born in Barcelona on 23 July 1890, and died therein on 17 January 1959. Amades was born into a working-class Barcelonese family and had to work from an early age in the family's antiquarian book business. In 1905 he started to attend courses offered by the Ateneu Enciclopèdic Popular de Barcelona (People's Encyclopaedia Association of Barcelona), an organisation meant to increase education standards among the working classes. Whilst there, he studied languages (French, English, German, and Esperanto) alongside other subjects, and he also participated in excursions into the countryside, aimed at collecting samples of traditional Catalan culture from various villages around Catalonia. Between 1915 and 1926, he collaborated in folklorecollecting projects organised by the Arxiu d'Etnografia i Folklore de Catalunya (Archive of Ethnography and Folklore of Catalonia) (1915-1923), and in the Obra del Cançoner Popular de Catalunya (Popular Song Project of Catalonia) (1922-1935). Although he was largely self-taught, he became one of the most highly respected Catalan folklorists. His most extensive works on Catalan folklore were published during the 1950s and dealt with folktales, traditions, and legends (Amades 1950), songs, proverbs, and riddles (Amades 1951) and customs (Amades 1950-56).

It can be seen from these two short biographies that the two folklorists came from very different backgrounds. Anderson received a university education and was a university lecturer, in short, he was an academic in every sense of the word. In contrast, Amades was self-taught and often expended great personal effort to compensate for his limited knowledge of scientific methods. Nevertheless, the two men shared two fundamental characteristics: a great collaborative spirit and an enormous capacity for work. 


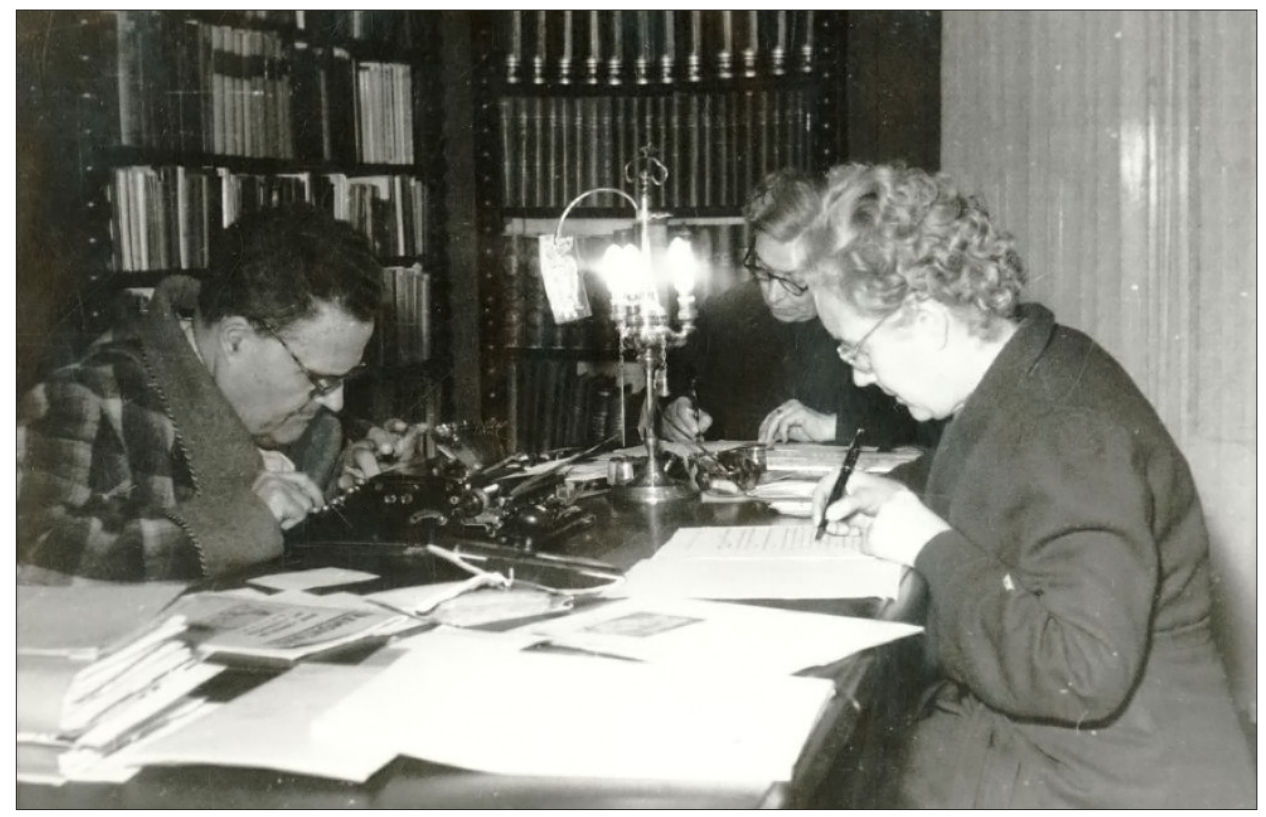

Figure 1. From left to right: Joan Amades, Enriqueta Mallofrè, his wife, and Consol Mallofrè, his sister-in-law, working in his home office in Barcelona in 1956. Fons Joan Amades: Centre de Documentació de Cultura Popular de la Generalitat de Catalunya, Barcelona.

Although Anderson and Amades belonged to the same generation of folklorists, their relationship only began in the later years of their lives, specifically in 1953, after Anderson had sent a letter to Amades. That same year, Anderson retired at the age of 68 and became professor emeritus of folklore at the University of Kiel, where he had worked since $1945 .{ }^{1}$ Meanwhile, Amades had held the position of curator of the prints and imagery section at the Museu d'Indústries i Arts Populars del Poble Espanyol in Barcelona from 1949 (Calvo 1990: 159, note 138$){ }^{2}$

During this period, Amades published Les cent millors rondalles populars (1948-1949) and Folklore de Catalunya: Rondallística (1950). These works were very well received by specialists, in particular those interested in comparative studies because Amades's works provided them with new tales that they could incorporate into their research.

Amades corresponded with the leading folklorists of the day in areas relating to the study of folktales, such as sharing versions, carrying out editorial projects, exchanging information on conferences, publishing articles, etc. Among others, Amades was in regular contact with Aurelio M. Espinosa, Ralf S. Boogs, Arnold Van Gennep, Paul Delarue, Stith Thompson, and Kurt Ranke; however, the 
folklorist with whom he most frequently corresponded was undoubtedly Walter Anderson.

The excellent relationship between Walter Anderson and Joan Amades can be seen in the content of the letters that Anderson wrote to Amades. After the latter's death, Anderson continued to correspond, for a short period, with Amades's widow Enriqueta Mallofrè, and her sister, Consol Mallofrè, who had collaborated on the many works that Amades published during his life (see Figure 1). All of this correspondence has recently been published (Oriol 2014) ${ }^{3}$ and is held in the Amades archive at the Catalan Government's Centre de Documentació de Cultura Popular in Barcelona. In this article, however, I will only study the letters that Anderson sent Amades since these constitute the main body of the letters that have been preserved. Unfortunately, it has proved impossible to locate the correspondence that Amades sent to Anderson, despite various attempts to do so. ${ }^{4}$

The aim of this study is therefore to ascertain the extent of the collaboration that took place between the two folklorists, and to examine the subjects that they discussed in their letters in the context of folklore studies of the time. Although we can only rely on the information provided in Anderson's letters, these are often sufficiently explicit to allow us to deduct part of the content of the letters sent by Amades.

\section{WALTER ANDERSON'S LETTERS TO JOAN AMADES}

Anderson's correspondence to Amades was written sporadically between 18 January 1953 and 5 December 1958. The documents consist of 26 letters and 5 postcards (although for practical purposes all of the documents are referred to as letters throughout this study) and their distribution by year is as follows: 7 were written in 1953; 5 in 1954; 1 in 1956; 10 in 1957; and 8 in 1958. More than half of the letters were therefore written in 1957 and 1958; that is, in the last two years of Joan Amades's life.

Anderson wrote all the letters in French. ${ }^{5}$ In the early letters, as is natural in any initial contact, he uses a very formal tone, while in the later letters the tone is more informal. For example, in the earlier letters he uses the closing formula En vous priant d'excuser mon audace (I beg your pardon for my boldness), whereas in the later ones he uses more informal expressions such as Mille saluts (A thousand greetings).

Another feature of the letters is their pedagogical tone, which is apparent not only in their content, but also in their form. Anderson writes his letters simply and clearly. He often organises the contents into numbered sections 


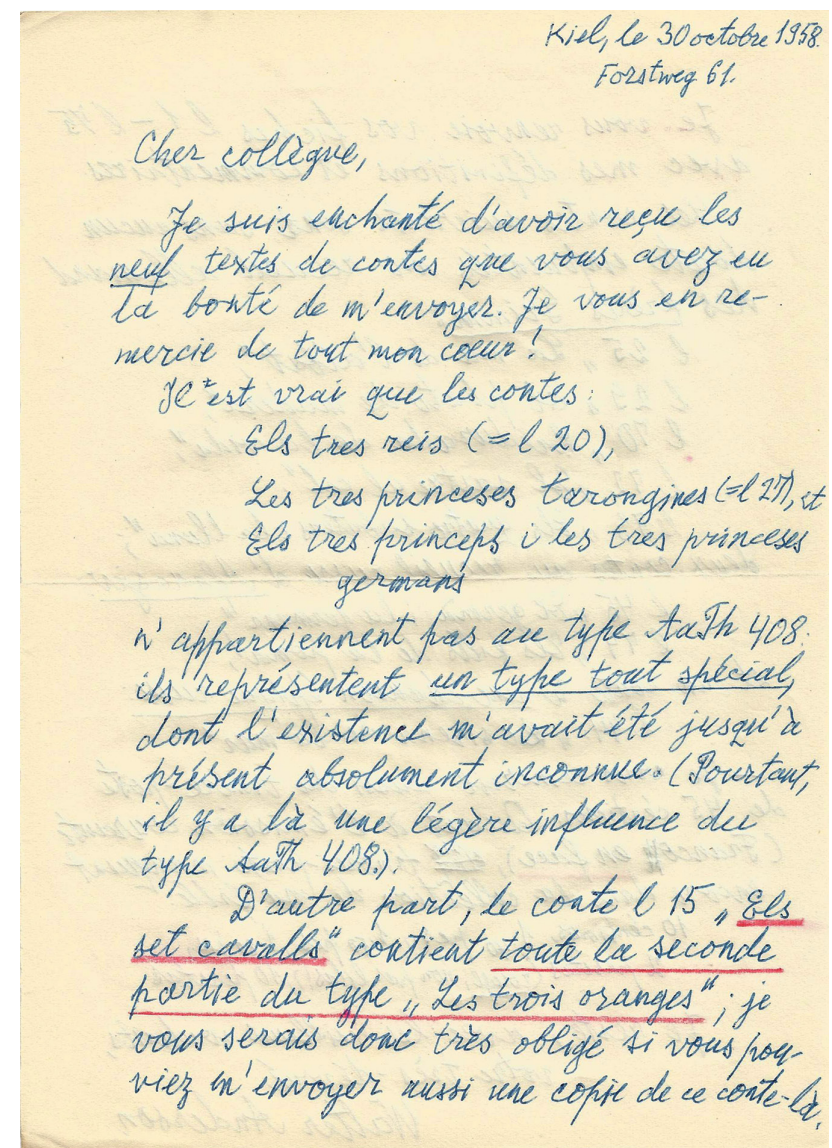

Figure 2. First page of a letter from Walter Anderson to Joan Amades, dated 30 October 1958. Fons Amades: Centre de Documentació de Cultura Popular de la Generalitat de Catalunya, Barcelona.

so that the issues addressed are well-structured. Furthermore, on many occasions he underlines words or phrases that he considers to be important in much the same way as a teacher would (see Figure 2). Indeed, in his letters Anderson undoubtedly acts as Amades's teacher and discusses theoretical and methodological aspects of the study of folklore, international folklorist associations, publications of interest, catalogues of folktales, cataloguing criteria, etc.

Meanwhile, Amades provided Anderson with texts and summaries of Catalan folktales for his comparative research and sent him information about tales published by Catalan folklorists (e.g. Valeri Serra i Boldú and Andreu Ferrer i Ginard) which Anderson was unaware of. The two folklorists also sent each 


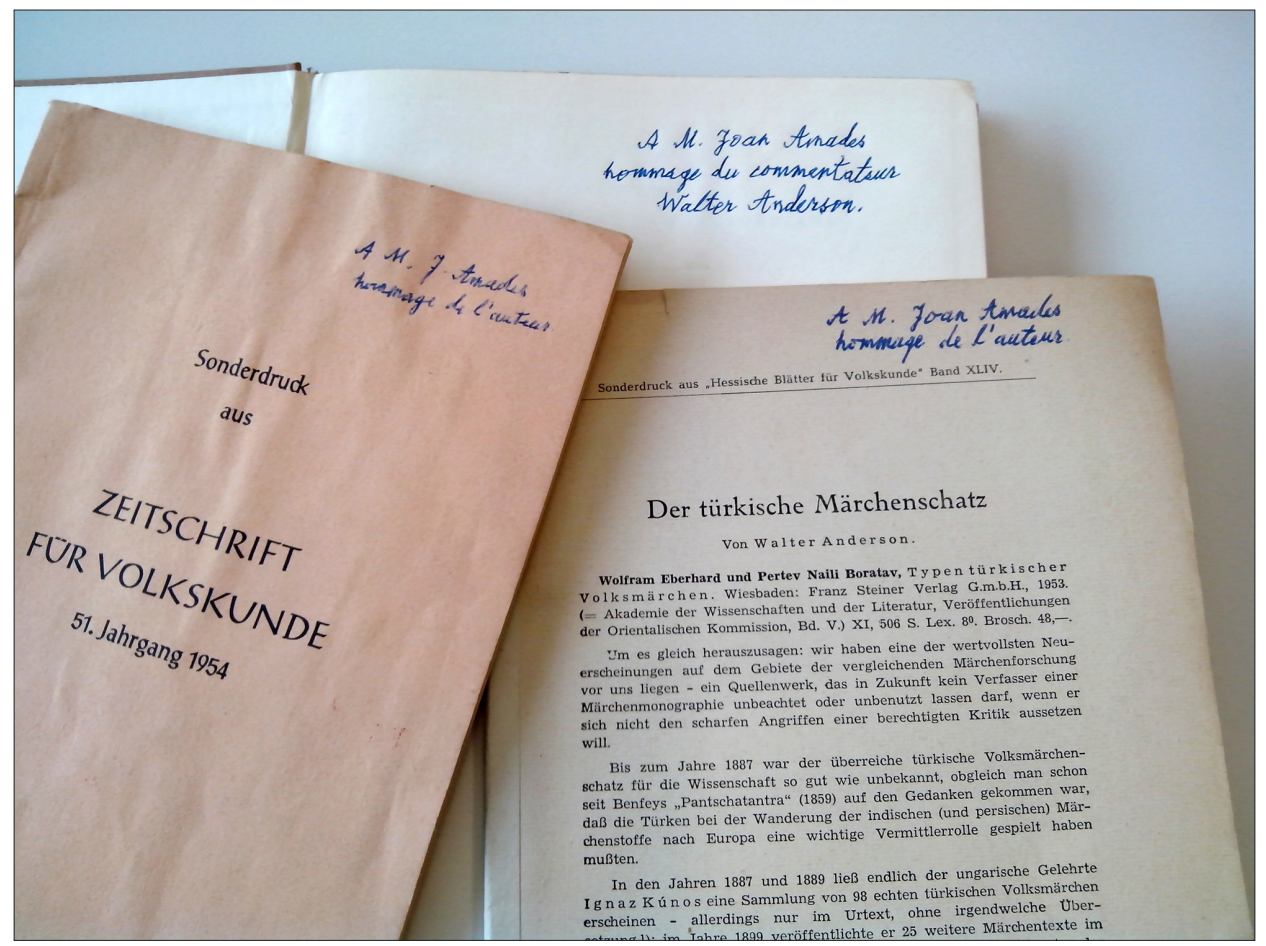

Figure 3. Publications with dedications by Walter Anderson. Fons Amades. Centre de Documentació de Cultura Popular de la Generalitat de Catalunya, Barcelona.

other books and articles that they had difficulty obtaining in their respective countries (see Figure 3).

\section{STUDY OF THE LETTERS}

Although Anderson's letters primarily deal with subjects relating to the study of folklore, he also occasionally provides biographical information about both folklorists. Consequently, the correspondence between the two men allows us to confirm information that we already know and to gather new information about their respective lives and work. Moreover, Walter Anderson's letters give us information provided by the author in the first person, thus making them important historical documents.

The nature and importance of the biographical information contained in the letters is illustrated by the following five points. 


\section{(1) Walter Anderson was a great polyglot}

Walter Anderson had an extraordinary ability to learn languages, which enabled him to successfully undertake so many comparative historic-geographic studies of folktales over the course of his life. ${ }^{6}$

In his first letter to Amades, dated 18 January 1953, Anderson, who was at that time working on a monograph on the tale of The Three Oranges, mentions the need to use versions of the folktale in various languages. In a later letter, dated 26 February 1953, Anderson says that knowledge of foreign languages is the greatest difficulty for those wishing to write a monograph on a folktale; he adds that it is necessary to at least understand all the Romance, Germanic, and Slavic languages (not only the literary languages but also the various dialects), or to have translations of texts written in these languages, which is very expensive. He then refers to his specific circumstances and says that he is relatively fortunate as he is able to understand texts in over forty languages (including Finnish, Estonian, Hungarian, Hebrew, Arabic, Persian, and Turkish).

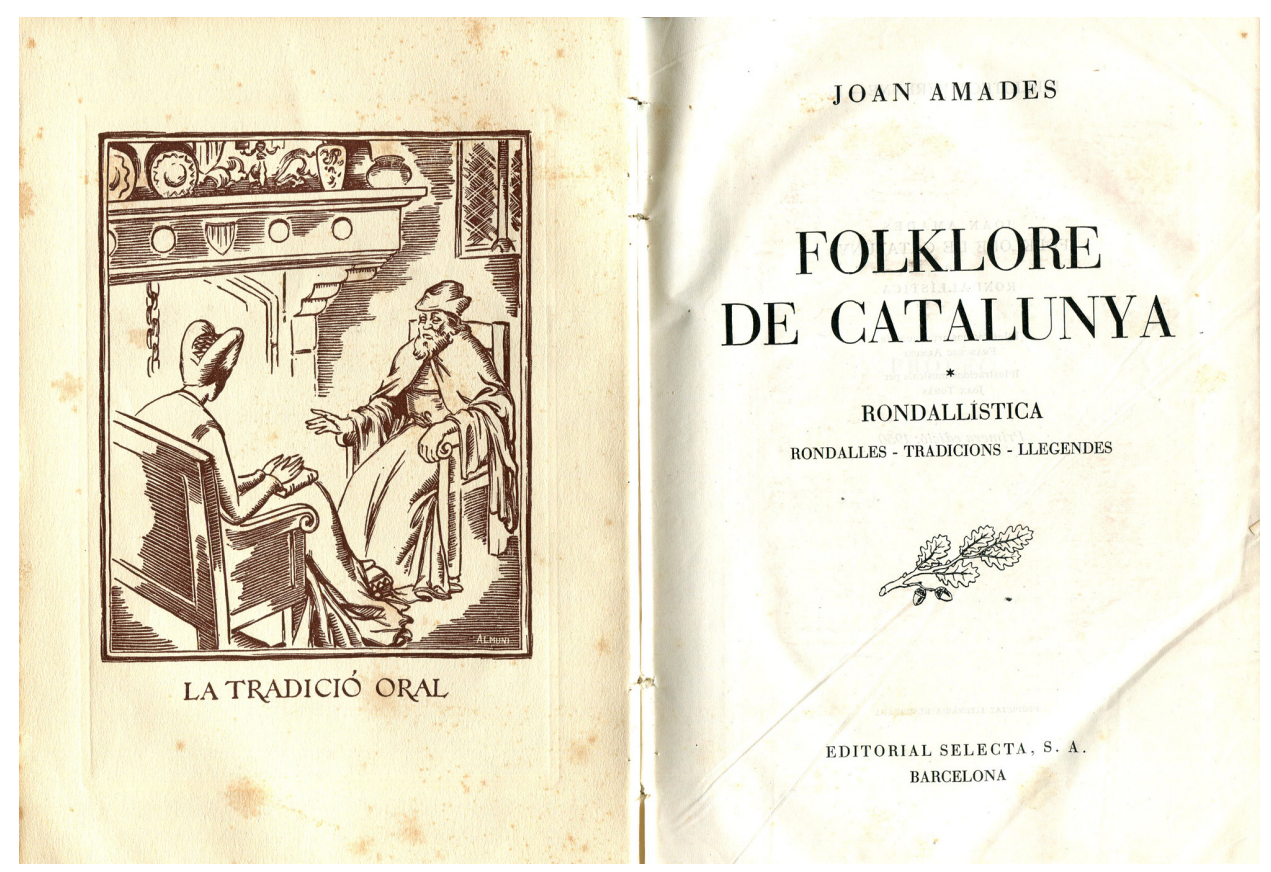

Figure 4. Frontispiece and cover of the first edition of the book Folklore de Catalunya: Rondallística (Amades 1950). 
Anderson understood Catalan, as he said in his first letter, which like all the others was written in French: "I understand Catalan and Spanish, but I do not know these two languages well enough to use them in my letters". ${ }^{7}$ Consequently, Anderson was able to read the folktales that appeared in the book Folklore de Catalunya: Rondallistica (Amades 1950), among others (see Figure 4). He was also able to understand the Majorcan dialect of Catalan, which in turn meant that he could read the Majorcan folktales collected in the books by Antoni M. Alcover, use them in his studies of comparative folktales, ${ }^{8}$ and catalogue them. ${ }^{9}$

Anderson's interest in languages, and in the Catalan language in particular, is highlighted in a letter written on 12 September 1957. In this letter, Anderson asks Amades about the meaning of the word clatell, which appears in the folktale L'amor de les tres taronges ${ }^{10}$ (The Love for Three Oranges) (ATU 408) and the folktale Maria Roseta ${ }^{11}$ (C-011). ${ }^{12}$ The word clatell $^{13}$ refers to the nape of the neck, and is much more widely used in Catalan than its synonym nuca. This is interesting because clatell belongs to a lexical family different from the corresponding terms used in other Romance languages. For example, in Spanish clatell is nuca, cogote, or cerviz, in French it is nuque, in Italian it is nuca, coppa, or collo, and in Portuguese it is nuca, pescoço, or cerviz. It is therefore difficult to guess the meaning of clatell by comparing the word with other Romance languages. This is undoubtedly why Anderson had difficulties understanding it and why, after mentioning that he had no access to a dictionary at the time, he asked Amades for the meaning of the word.

\section{(2) Walter Anderson lost his entire library as a result of the war}

One of Anderson's letters, dated 21 September 1957, discusses the loss of his library during the siege of Königsberg, which took place at the end of the Second World War, in 1945. This siege led to the destruction of almost the entire city and its annexation by Russia, under the new name of Kaliningrad. Anderson's loss of his library has been mentioned by other authors including Levin (1963: 294) and Seljamaa (2005: 159), and indeed Anderson himself briefly refers to it in one of his letters to Amades:

As regards the three works you would like to see, I cannot send you my own copies as they have been destroyed (as were all my books and manuscripts) during the siege of Königsberg (1945); however, you will soon receive three books from the commissioner of the Finnish Academy of Sciences, and I would ask you to accept them as proof of my gratitude. ${ }^{14}$ 


\section{(3) Joan Amades was a member of Folklore Fellows}

We know about Amades's membership of Folklore Fellows thanks to the information contained in Anderson's letters. During those years, the association operated in a highly unusual manner, as we will see below.

Anderson had told Amades about the organisation's existence in his letter dated 26 February 1953, and Amades must have asked him for further information about it because in his letter dated 4 April 1953, Anderson refers to it in the following terms:

The organisation Folklore Fellows in which you are interested is a very strange organisation; it has no president, no committees, no branches, no budget, no meetings, no minutes, and no reviews. ${ }^{15}$

He then explained that almost all of these items had been planned when the federation was founded (in 1907), but had not been implemented because they were considered superfluous. Anderson made his own personal assessment by saying:

The Federation is somewhat similar to the Republic of Letters imagined by Erasmus of Rotterdam: one becomes a member either by declaring (or by showing) that one is willing to help other folklorists with their studies - and now you are a member, as I am. If any folklorist is in need of any Catalan folklore material, I shall give them your address - in the same way as I received yours from Mr. Paul Delarue. And if you need materials, bibliographical information, etc., I and all the other folklorists will be happy to assist you. That is all; there are no formalities or membership lists; I myself am a member of the editorial board of the FF Communications (the Federation's only committee), i.e. the series published on behalf of the Folklore Fellows and funded by the Finnish Academy of Sciences. Since 1926, my name, together with another five names, has been on the covers of all volumes in this series (there are now 60, consisting of 144 issues), and yet neither I nor my other five colleagues (including Professor Martti Haavio, who is the head of the committee) possess any documents to show that we are editors (or even members of the Federation). ${ }^{16}$

The statutes of Folklore Fellows (Statuten des Bundes "FF") are recorded in a short text of ten paragraphs, which was published in Volume 4 of the collection Folklore Fellows' Communications (Krohn 1910). 


\section{(4) Walter Anderson and Joan Amades were both keen philatelists}

Anderson's interest in numismatics is well known (Ranke 1962, 1977: 494), but his letters also reveal to us that he was a keen philatelist and that he must have passed this interest in stamp collecting on to his daughter because at the end of the letter dated 30 October 1958, Anderson tells Amades which stamps his daughter needs for her collection. And in the last letter Anderson wrote to Amades, dated 5 December 1958, he thanked him for the two stamps and the folktales he had been sent.

After the death of Amades, Anderson continued a brief correspondence with Amades's wife and sister-in-law, as mentioned above, and the content of one of these letters shows that they also sent him stamps. Thus, in the letter dated 21 December 1960, Anderson includes a postscript stating: "Merci beaucoup aussi pour les 49 timbres-poste!" (Thank you also for the 49 stamps!).

We know that Amades and his sister-in-law were also avid stamp-collectors ${ }^{17}$ because of the stamp albums kept in the Amades archive in Barcelona.

\section{(5) Walter Anderson and Joan Amades met in person}

Anderson's letters show us that the two folklorists met in person. The letter dated 1 September 1954 mentions the first meeting between the two folklorists at a congress in Naples. In this letter Anderson says that he has seen Amades's name on the list of those attending the congress in Naples and is looking forward to meeting him in person because, notwithstanding any unforeseen difficulty, he also plans to attend. In the biography of Amades (Calvo 1990: 236), the only congress that Amades is known to have attended in Naples in 1954 was the Congresso Internazionale di Etnografia e Folklore del Mare, which took place on October 3-10. At the congress, Amades presented the communication under the heading Rito di una construzione di una barca. ${ }^{18}$ However, I have been unable to confirm that this is the congress Anderson refers to or indeed if the two folklorists actually met on this occasion.

In another letter dated 29 May 1958, Anderson refers to two more meetings that took place in 1955 and 1958 respectively. The letter does not provide enough information to ascertain where the 1955 meeting took place; however, it is more explicit regarding the 1958 meeting. In this letter, Anderson writes:

I hope to visit you in Barcelona at the end of June. I intend to participate in a congress to be held in Porto from 18 to 23 June (Colóquio de estudos etnográficos Dr. José Leite de Vasconcelos). I will travel (if the political situation permits) via Irun, but I will return via Barcelona, where I plan to stay for one or two days. ${ }^{19}$ 
Anderson's letter crossed paths with those that Amades wrote to him on 30 May and 1 June 1958. In these letters, Amades must have told Anderson that he also intended to attend the conference in Porto because in Anderson's next letter, dated 6 June 1958, he acknowledges receipt of the two letters from Amades and concludes with “Au revoir à Porto!" (See you in Porto!). We also have a photograph in the Amades archive in Barcelona showing that the two folklorists met at this conference (see Figure 5).

In addition to these essentially biographical data, Anderson's letters provide information about his professional work as a folklorist and feature comments and explanations on a whole range of subjects, including a monograph titled The Three Oranges (ATU 408), international folklore associations and archives, an article titled A Folklore Experiment, a review of the book Folklore de Catalunya: Rondallística (Amades 1950), the concept of the folktale, a project for cataloguing Catalan folktales, and a catalogue of Catalan etiological legends.

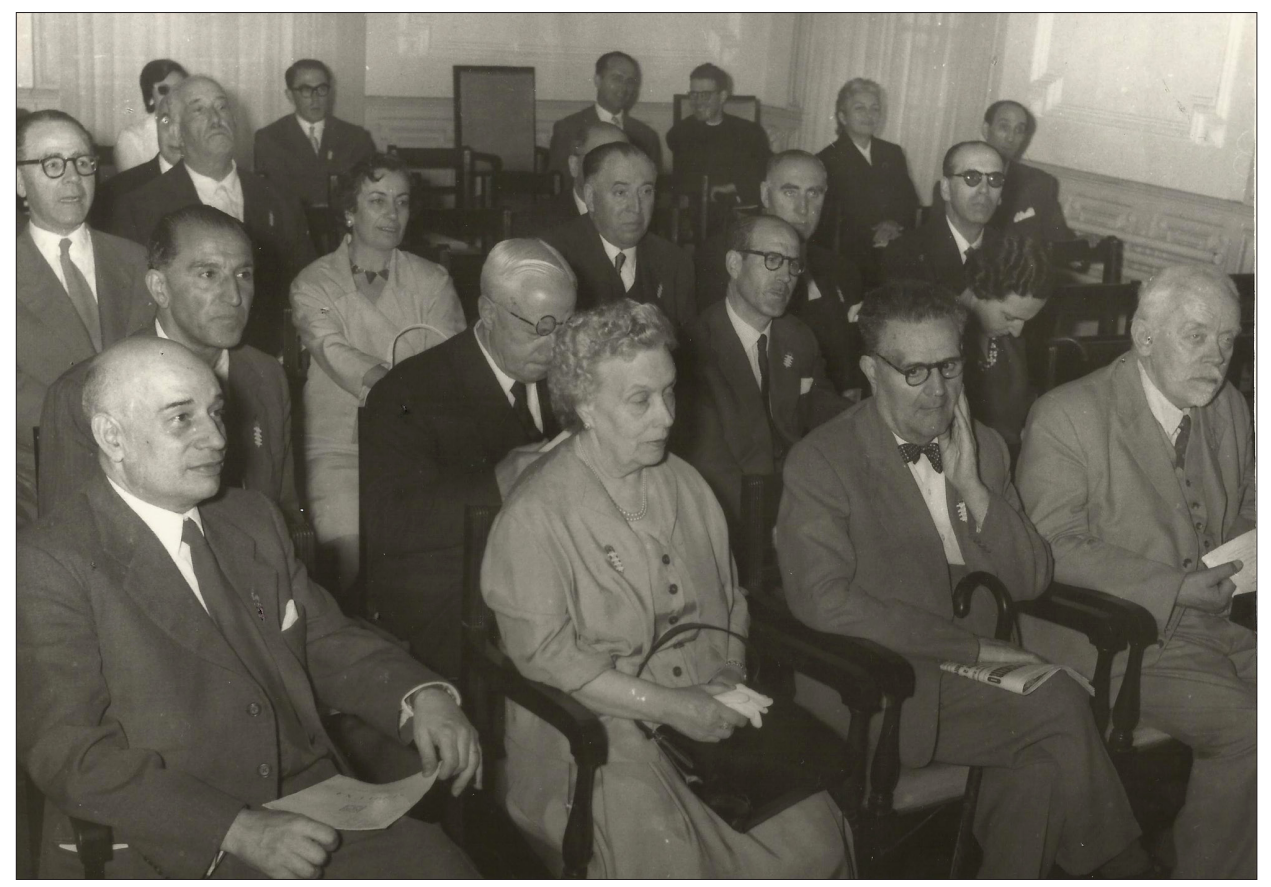

Figure 5. First row from right to left: Walter Anderson and Joan Amades with his wife, Enriqueta Mallofrè, at the Colóquio de estudos etnográficos "Dr. José Leite de Vasconcelos”, Porto, 1958. Fons Amades: Centre de Documentació de Cultura Popular de la Generalitat de Catalunya, Barcelona. 


\section{THE THREE ORANGES MONOGRAPH (ATU 408)}

Walter Anderson, who had been working on the monograph of the tale of The Three Oranges for some years ${ }^{20}$ heard of the existence of two Catalan versions in the volume Folklore de Catalunya: Rondallística (Amades 1950), as a result of his collaboration with the French folklorist Paul Delarue. Specifically, Delarue sent Anderson the texts of folktales No. 62, Les tres taronges de la vida (The Three Oranges of Life), and No. 93, L'amor de les tres taronges (The Love for Three Oranges). This led to Anderson's first letter to Amades on 18 January 1953, in which he asked him to clarify some questions regarding these versions and whether he had other manuscript versions of the folktale. Anderson was studying the tale of The Three Oranges from the historic-geographic perspective, hence his remark to Amades that he was attempting to compile all the versions of the folktale in existence, and that he had already compiled more than two hundred from Europe, America, Africa, and Asia (where the story is well known even in China and Korea).

The historic-geographic method aims to determine where and when a folktale originated and how it has spread; consequently, researchers who use it need to collect as many versions from as many countries as possible.

Amades must have replied that he had no manuscript versions of the tale and seems to have sent him a list of published versions instead, because Anderson, in his letter dated 5 February 1953, tells him that he knows of all of them except the one by Valeri Serra i Boldú, Rondalles populars (Serra i Boldú 1930: 45), and says he would be very grateful if he could copy this text for him and send it.

Rather than the complete text, Amades sent him a summary of the folktale, because on 15 February 1953 Anderson thanks him for his highly detailed summary and then asks a series of questions relating to the version, including:

(1) Are the giant's eyes open while he is asleep (and closed when he is awake) or not? (2) Does the witch stick the enchanted needle in the girl's ear or elsewhere on her head? (3) Does the girl turn into a dove or another bird? (4) Does the witch promise the prince that she will become beautiful again or not? (5) Does the bird come to the prince's garden to talk to the gardener three times, or not? (6) If so, what do the bird and the gardener say ${ }^{21}$

Then Anderson, in a very cordial tone, says that he regrets having to ask so many questions, but that it is precisely these minor details that enable him to reconstruct the history of the development and migration of the folktale.

In the following letter, dated 26 February 1953, Anderson thanks Amades very warmly for replying to his questions on the Serra i Boldú version, and for 
sending him three new Catalan versions of the tale of The Three Oranges. Anderson believes that the Catalan tradition of the folktale is well represented as he has thirteen versions of it. In the same letter, he says that he cannot begin writing his monograph before the end of the year, as he still needs some important texts published in books that are relatively inaccessible. For this reason, he will still be able to use any materials that he finds or that are sent to him.

Amades was willing to help him, and continued to send him versions of the folktale. We know this, for example, from the letter dated 16 October 1954, in which Anderson thanks him for sending three unpublished versions of The Three Oranges and says that he will use them in the analysis of the folktale to reconstruct its original form and the subsequent evolution, and he will mention the Arxiu Històric Municipal de Barcelona (see Figure 6). ${ }^{22}$

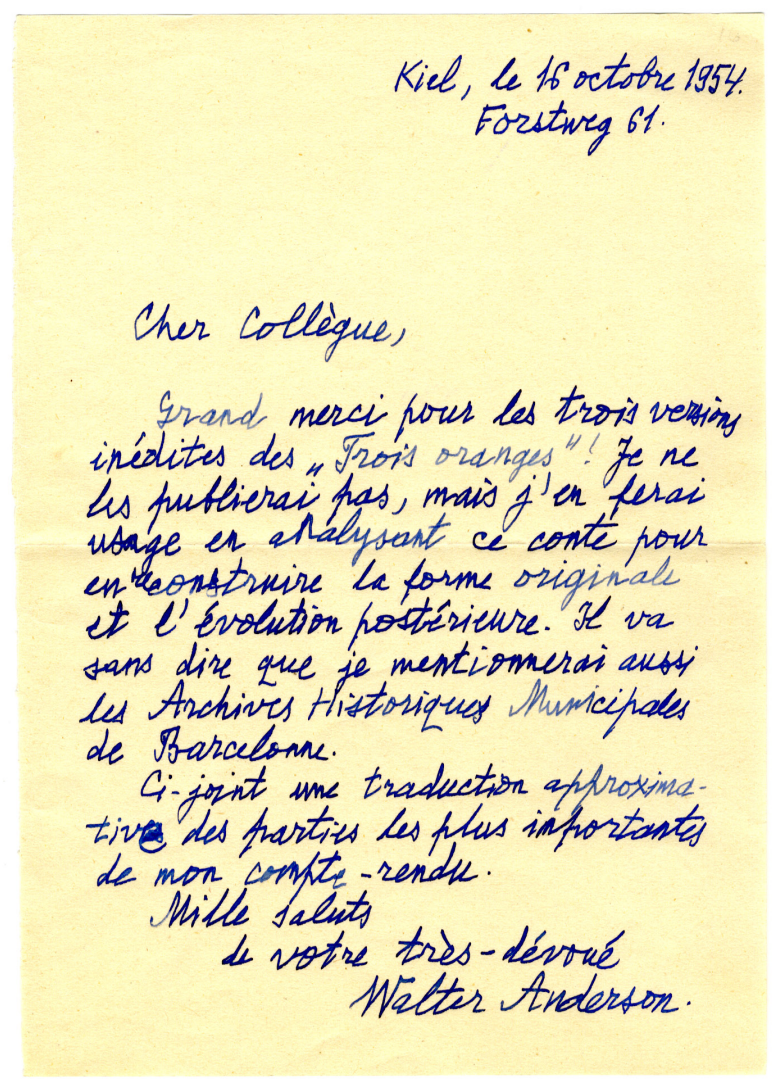

Figure 6. Letter from Walter Anderson to Joan Amades, dated 16 October 1954. Fons Amades: Centre de Documentació de Cultura Popular de la Generalitat de Catalunya, Barcelona. 
Anderson never published the monograph about the tale of The Three Oranges. The text is preserved in the archives of the Enzyklopädie des Märchens and consists of 746 handwritten sheets of A5 paper. ${ }^{23}$ Anderson used a total of 22 Catalan versions (as can be seen in the text of the manuscript) with the RC code followed by the corresponding number. The letter ' $R$ ' indicates that the version is Romance, and the letter ' $\mathrm{C}$ ' shows that it is Catalan. However, the manuscript is incomplete and lacks the part containing the bibliographical references; we are therefore unable to ascertain which Catalan versions Anderson used.

In the second revision of the Aarne-Thompson catalogue (1961), Walter Anderson was responsible for the description of type 408, The Three Oranges (as explicitly stated), and the monograph he was preparing was cited as a paper intended for publication in the near future, although, in the event, this never happened.

\section{INTERNATIONAL ASSOCIATIONS AND FOLKLORE ARCHIVES}

In his letter dated 26 February 1953, Anderson discusses Nordic folklorists' organisations, which indicates that in his previous letter Amades must have shown some interest in them. Anderson refers to them in the following terms:

The Nordic folklorists' organisations you referred to are not special societies, but are instead archives in which a nation's entire folklore material (printed or handwritten) is compiled and preserved. These archives can be found in Copenhagen, Oslo, in various parts of Sweden, Helsinki, Tartu, and Riga. In Germany, there are the archives of folk songs and tales in Fribourg, and the folktales archives in Marburg. Even the great Folklore Fellows is not really a truly international society, but instead an ideal league of all the world's folklorists who have pledged to help each other in their studies. ${ }^{24}$

Anderson then discusses the books in the FF Communications collection, as Amades must have asked him if it was possible to publish them in Catalan. In response, Anderson explains that they are an international series published on behalf of Folklore Fellows by the Finnish Academy of Sciences but that at the time of writing all of its publications had always been in German, English, or French. He then goes on to point out that neither of Finland's two (very different) official languages, Finnish and Swedish, had ever been included in this series. He concludes by suggesting that perhaps something in Italian could be published, whereas Spanish would be much more doubtful, and a work in 
Catalan would have very few readers. He concludes by saying: "Knowledge of your beautiful language is unfortunately very limited in the world". ${ }^{25}$

\section{THE 'FOLKLORE EXPERIMENT' ARTICLE}

Anderson sent Amades a copy of his work titled Ein Volkskundlische Experiment (Anderson 1951) ${ }^{26}$ and, in his letter dated 26 February 1953, he briefly explains its contents as follows:

Over thirty years ago, I established a theory that every man who tells a folktale has heard it not only once in his life, but instead many times and from many different people; otherwise, the folktale would constantly be changed and distorted until it would soon be unrecognisable. ${ }^{27}$

Anderson's comment refers to one of his major contributions to the study of folklore of the time: the Law of Self-Correction. This law was formulated by Anderson in the monograph type ATU 923, Kaiser und Abt (The Emperor and the Abbott) (Anderson 1923), and he says in his letter: "This thesis was opposed by many folklorists who did not want to believe it". ${ }^{28}$

He then explains the experiment he has carried out, which is at the heart of the work he sent to Amades:

In order to resolve the issue, I read a (little-known) legend to three students at our university, and asked them to write it down the next day just as they remembered it at that time, and then asked each one to read it to another student, who would do the same the next day; and this procedure was repeated twelve times. As a result, I obtained three sets of twelve texts each, and the final texts in these series (A12, B12, C12) were all totally distorted and with major discrepancies between them, which was exactly what I had expected. Twenty years ago, I carried out some similar experiments in Estonia (without publishing the results); the results were absolutely identical. ${ }^{29}$

The theses that Anderson put forward in his work became the focus of debate not only among contemporary folklorists but also among future generations. This can be seen, for example, in the extensive bibliography that accompanies the article Experimentelle Erzählforschung, published in the Enzyklopädie des Märchens (Oring 1984). 


\section{THE REVIEW OF THE BOOK \\ FOLKLORE DE CATALUNYA: RONDALLÍSTICA}

In his letter dated 26 February 1953, Anderson tells Amades that if the latter sent him some of his work, Anderson would be happy to review it in a Swiss or German folklore journal. A subsequent letter, dated 1 October 1953, tells us that Amades sent him the two volumes of the anthology, Les cent millors rondalles populars (Amades 1948-1949), ${ }^{30}$ because Anderson thanks him for doing so and says that he has taken many notes although he admits that he has still not had time to write the review he promised as he is in the middle of some other urgent work.

However, in the following letter, dated 11 February 1954, Anderson says that instead of publishing a review of the anthology, he has decided to write one about a large collection, amounting to 1,735 pages, which has been brought to him from Spain. The work Anderson is referring to is undoubtedly Folklore de Catalunya: Rondallística (Amades 1950). In the same letter, Anderson adds that he is studying Amades's unique collection, that his review will be about a dozen pages long, and that this review will mention Amades's anthology (in two volumes).

This decision is not surprising given that Anderson greatly admired the size and breadth of this book and found it very useful in his comparative studies (see Figures 7 and 8). For this reason, in the letters dated 18 January 1953 and 11 February 1954, he describes the work as a "monumental collection" 31 and a "unique collection" respectively. ${ }^{32}$ In the later letter ${ }^{33}$ he also says:

Reading your great book has given me many surprises: when reading folktale no. 231, "The man who turned into a donkey", my eyes widened: this folktale has been very well known in Germany since the Thirty Years' War (the versions include two from the seventeenth century), a folktale that is probably derived from the novel by Apuleius and which I was very familiar with as I studied it about forty years ago! But I did not have the slightest idea that the tale was known to other peoples - and especially to the Catalans! ${ }^{34}$

And in yet another letter ${ }^{35}$, Anderson writes, "It is impressive to read that you have compiled so many folktales and songs: 15,000 is a huge number". ${ }^{36}$

Anderson reviewed Amades's book (Anderson 1954) in which he catalogued the folktales according to the Aarne-Thompson system (1928). In a later letter, dated 16 October 1954, Anderson sent Amades a rough translation (in French) of the most important parts of the review. Anderson basically emphasises two aspects: (1) the length of the book, which contains a total of 2,215 numbers cor- 

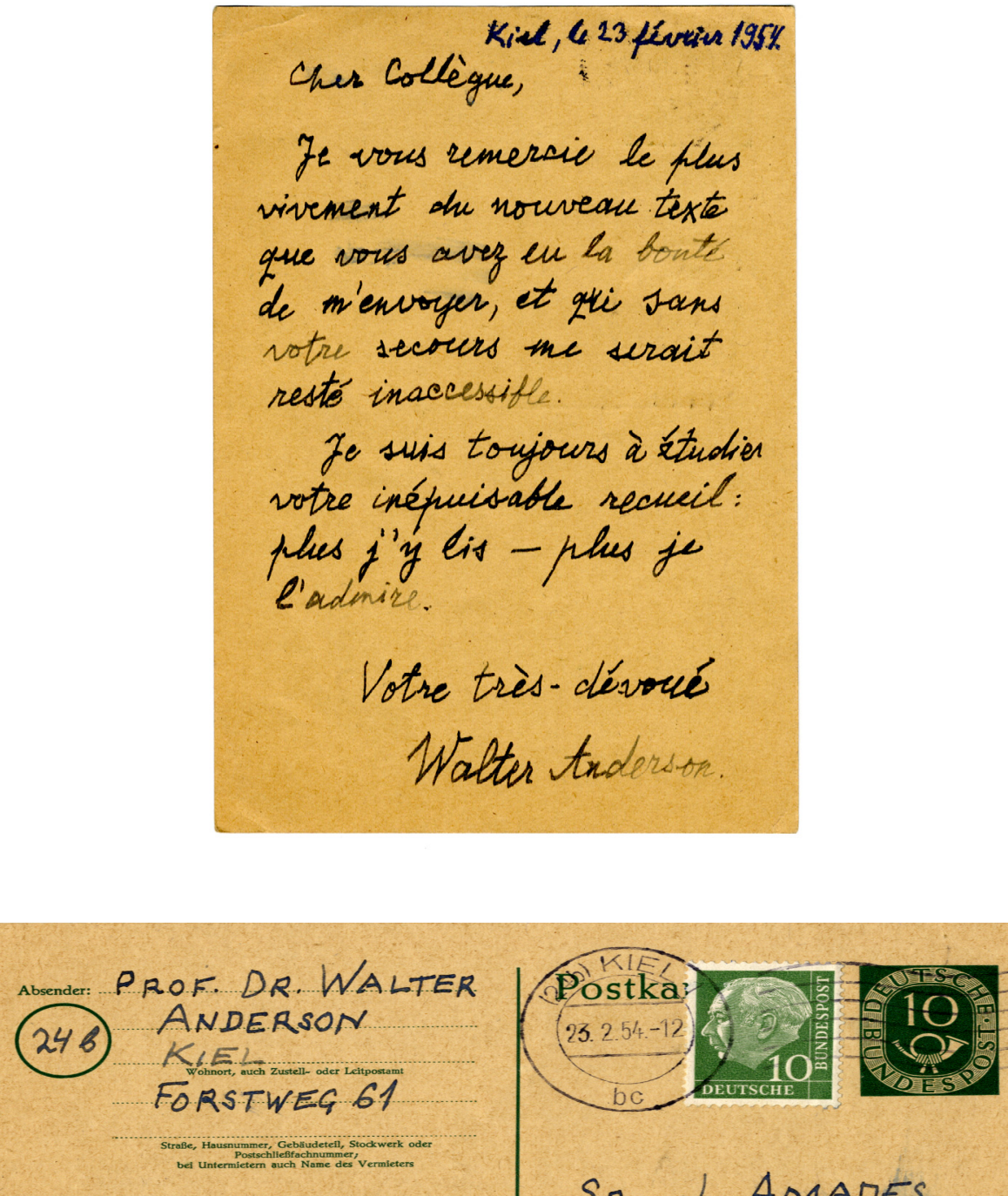

$S_{R}$ J. AMADES PROVENZA, 209 BARCELONA (ESPAC,NE)

Figures 7-8. Postcard from Walter Anderson to Joan Amades, dated 23 February 1954. Fons Amades: Centre de Documentació de Cultura Popular de la Generalitat de Catalunya, Barcelona. 
responding to folktales, stories, and legends; and (2) its importance to specialists due to its richness and variety.

Because of these characteristics, Anderson felt it was necessary to catalogue the folktales in Amades's book, giving the following explanation:

If a specialist is looking for versions of a given folktale, how will he fish for them in the ocean of the Catalan book? Versions of the same folktale are often scattered in different places, such as wonderful true folktales (due to an accidental location) in the chapter on legends of castles. Will the specialist have to follow my example, sacrificing many weeks studying the Catalan book? That is not something everyone can do! In order to at least partially remedy this problem, the following table shows the numbers under which the reader will find the tale-types stipulated by Aarne and Thompson. ${ }^{37}$

The catalogue included in Anderson's review (1954) does not exactly match the one included in the second revision of the Aarne-Thompson catalogue (1961), as has been highlighted by Oriol (1990). The causes for the differences between these classifications are unclear. On the one hand, Thompson would undoubtedly have used the catalogue published by Anderson. However, on the other hand, Anderson himself subsequently modified his own cataloguing system. Evidence of some of the amendments made by Anderson can be found in his letter to Amades, dated 29 May 1958, in which he includes a short list of types with the corresponding corrections (see Figures 9 and 10).

However, Anderson would not have sent these amendments to Thompson, who at that time was working on the second revision of the international catalogue (Aarne \& Thompson 1961). This is made clear by Anderson in a letter dated 30 January 1958, in which he says that he has not sent the amendments to Thompson and that Amades must contact him himself. As can be seen in the same letter, Anderson intended to revise the way in which Folklore de Catalunya: Rondallistica (Amades 1950) was catalogued, and to send Amades a copy of this revision so that he could use it in his own catalogue. Anderson soon put his intention into effect when in his letter dated 29 May 1958 he sent Amades a 45-page review of the folktales contained in Amades's book.

\section{THE CONCEPT OF THE FOLKTALE}

Amades must have soon told Anderson that he was having difficulties in defining the term 'folktale' and that this was a problem for him because he was thinking of producing a catalogue of Catalan folktales and he needed to be able to 


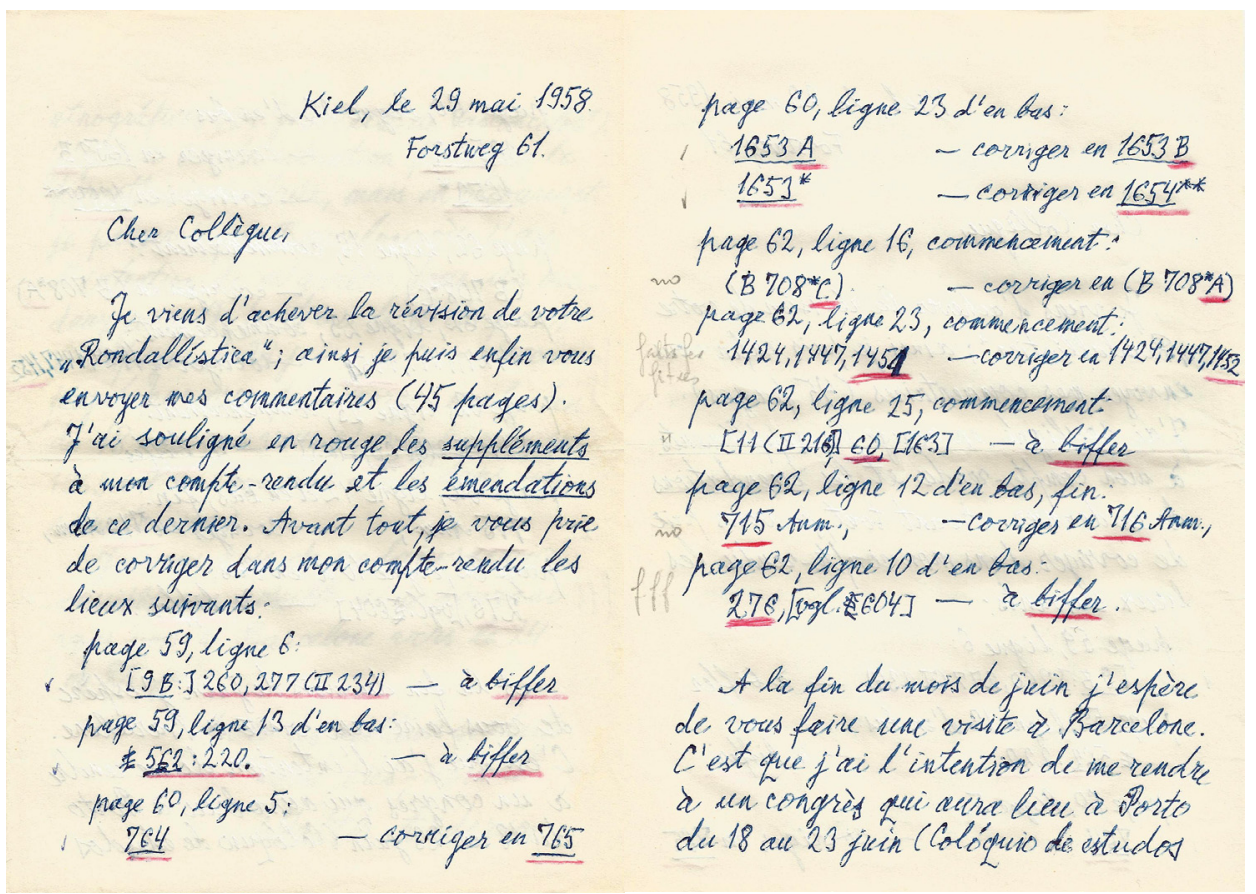

Figures 9-10. Initial pages of the letter from Walter Anderson to Joan Amades, dated 29 May 1958. Fons Amades: Centre de Documentació de Cultura Popular de la Generalitat de Catalunya, Barcelona.

decide which ones he should include (Oriol 1999: 370). This would explain the following excerpt from Anderson to Amades, dated 1 October 1953:

As regards the definition of a folktale, I must confess that I am not particularly concerned with definitions and classifications - certainly less than you are, as a compatriot of Ramon Llull. There are so many things in the universe that defy rigorous definition - so many transitional or hybrid forms that cannot be classified. I would call a 'folktale' a narrative of something that happened once, but not of something that often happens in the present. Many savage peoples believe that the sun or the moon is devoured by a monster during each eclipse, and then emerges from its belly: that is not a folktale, it is a belief. The Russians say that the earth rests on three giant whales, whose tremors cause earthquakes: that is also a belief, not a folktale. However, there are also peoples who believe that in ancient times, there were 10 suns in the sky that mercilessly scorched the land, until a hero killed nine of them with his arrows: that is a genuine folktale - an etiological folktale. 
There are folktales that explain the origin of a proverb or a riddle, or a teasing nickname: these are always folktales; but fingerplays are not: they are instead small representations rather than folktales. I would also not classify mathematical problems [---] or the texts that you call 'embarbussaments' [tongue-twisters] as folktales. ${ }^{38}$

It can be seen here that Anderson approaches the issue of genres of folktales with a certain degree of pragmatism. This is hardly surprising from someone who had read, studied, and catalogued thousands of texts over the years and was therefore aware of their diversity. So he decided to offer Amades an explanation that aimed, above all, to be practical and avoided sweeping definitions.

In the same letter, Anderson explains to Amades the differences between the books Motif-Index of Folk Literature (Thompson 1932-1936) and Types of the Folktale (Aarne \& Thompson 1928), which Amades must have asked about with regard to cataloguing Catalan folktales. This may have been related to the fact that Amades had been commissioned by UNESCO to produce a bibliography and classification of Catalan folktales. Although it has been impossible to ascertain precisely how this commission came about, Walter Anderson and Paul Delarue both seem to have played a part in it, particularly because the latter was secretary of a UNESCO committee devoted to the study of folktales (Calvo 1990: 172, note 187).

\section{THE CATALAN FOLKTALE CATALOGUING PROJECT}

From 1954 onwards, the collaboration between Anderson and Amades focused mainly on the task of cataloguing Catalan folktales. In a letter dated 1 September 1954, Anderson is keen to help Amades obtain the Aarne-Thompson catalogue (1928). He says: "I will do everything possible to send it to you within a few weeks". ${ }^{39}$

In an undated letter from 1954, Anderson gives clear instructions about which tales need to be catalogued. He says:

You were right: preparing a national catalogue of folktales is an extremely useful task, but also a very extensive and difficult one. If possible, all the folktales must be recorded, including those which have been published in almanacs, magazines, newspapers, etc., and those that have not been published, as well as those that have been printed in books for children, provided that they are not artificial re-workings of texts already recorded in your catalogue. 
However, you do not have to take into account local legends about fairies, giants, mermaids, etc., those about fabulous countries and ships, or legends about the lives of saints or religious miracles. Those things are very interesting, but they require a special catalogue.

As for anecdotes and jokes, as many as possible should be recordedand at least all those named in the Aarne-Thompson catalogue. However, purely local anecdotes (e.g. blason populaires, etc.) may be omitted, as well as interpretations of birdsong and mathematical problems. ${ }^{40}$

Anderson goes on to explain the criteria he used to catalogue the folktales in the book Folklore de Catalunya: Rondallística (Amades 1950). He says:

Reading your great collection, I have not recorded all your folktales, but instead only those listed in Aarne and Thompson's catalogue, and those that are missing from it but which are nonetheless very well-known and important. I have covered all of this in my review. ${ }^{41}$

It is clear from this that Anderson was undoubtedly an expert cataloguer whereas Amades was only just beginning to familiarise himself with the process. Therefore, Amades must have been incredibly grateful for the following offer that Anderson made in the same letter: "If you have any concerns about any folktale, send me a brief summary of it or the appropriate number in your Rondallistica and I will give you my opinion". 42

Between 1954 and 1957, Amades was working on editing the book titled Contes Catalans (Catalan Tales), which Delarue had commissioned for the collection Contes des Cinq Continents (Tales from Five Continents) (Amades 1957) (see Figure 11). The annotations on the informants were provided by Amades, while Anderson was responsible for cataloguing the folktales.

Figure 11. Bookplate from the back cover of the book Contes Catalans (Amades 1957). Fons Amades: Centre de Documentació de Cultura Popular de la Generalitat de Catalunya, Barcelona.

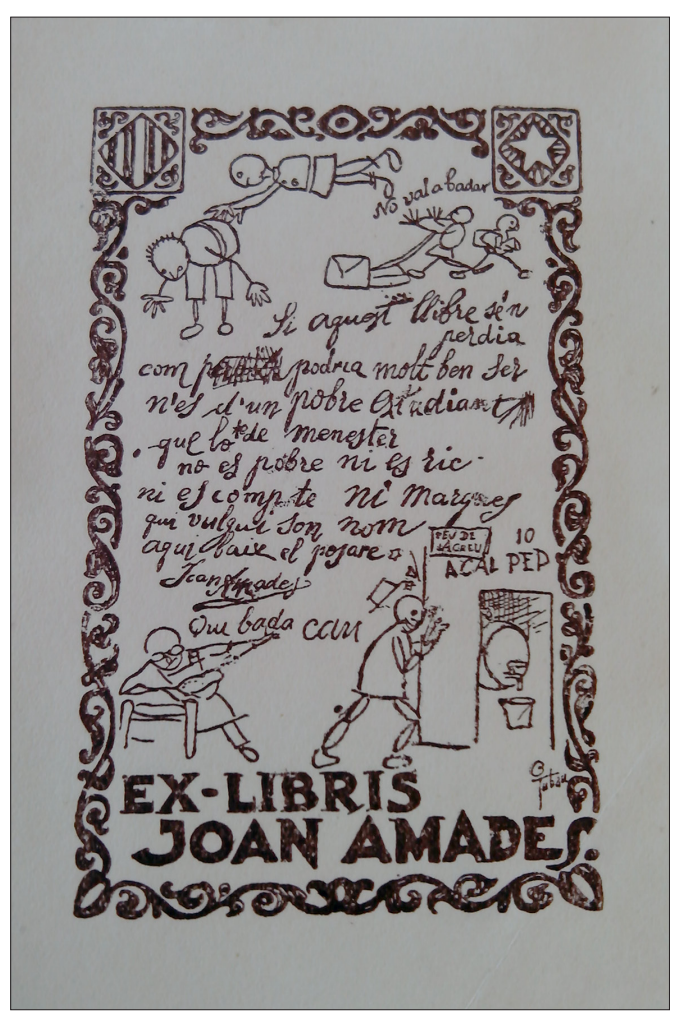


The correspondence between Anderson and Amades intensified in 1957 with the most frequent subject continuing to be the cataloguing of folktales. In his letter dated 10 April 1957, Anderson sent a postcard to Amades, in which he says that he would be delighted to classify the folktales from all the collections sent to him as his Rondallistica is the only Catalan collection in the libraries of his city. He goes on to insist: "In general, I will do everything possible to help you in your undertaking". ${ }^{43}$

On 2 May 1957, Anderson informs Amades that he has received the fourteen volumes by Alcover, although he also says that he would need a few weeks to read and classify these long folktales. He then states that he has only received volumes I-VII and IX-XV, that perhaps stocks of volume VIII have run out, but that he will be able to order it from the Lateinamerikanische Bibliothek in Berlin (which has volumes I-XIV) ${ }^{44}$ (see Figure 12).

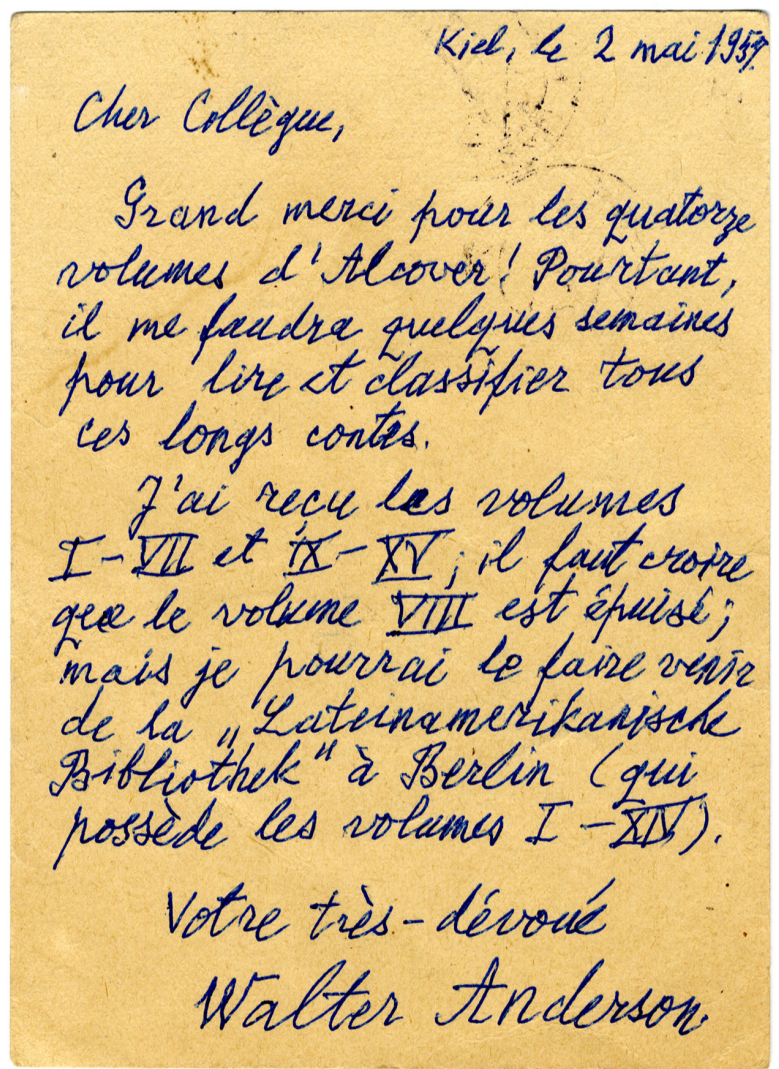

Figure 12. Postcard from Walter Anderson to Joan Amades, dated 2 May 1957. Fons Amades: Centre de Documentació de Cultura Popular de la Generalitat de Catalunya, Barcelona. 
Throughout 1957, Amades must have immersed himself in cataloguing Catalan folktales, collecting books of folktales and selecting material to send to Anderson $^{45}$ because in the letter dated 25 August 1957, Anderson once again clearly acts as Amades's mentor when he says:

You ask me to clearly explain to you which folktales have been excluded from the Aarne-Thompson system. Unfortunately, this is almost impossible; we would need a new Ramon Llull to give you all the definitions, distinctions, and classifications that you would like. We can say that in general, religious, biblical, etiological, historical, and local legends are excluded from this system; separate catalogues are produced for all the folktales in these genres. ${ }^{46}$

Anderson then tells him that the numbers of the types missing from Folklore Fellows Communications volume 74, that is the Aarne-Thompson catalogue (1928), will be determined by Mr. Thompson himself, who is now preparing a new edition of his catalogue. He then continues: "To facilitate your work, I intend to review your Rondallistica in order to complete the index I have published in the Swiss archives of folk traditions". ${ }^{47}$ He concludes: "I look forward with great interest to receiving the collections of Catalan folktales that you have been kind enough to tell me about". ${ }^{48}$

Anderson's involvement in Amades's classification of Catalan folktales was so important that Amades must have proposed to him that both men appear as joint authors of the future catalogue, because in his letter dated 12 September 1957 Anderson says:

As for your suggestion, I will with great pleasure do everything to help you in your undertaking, in which I take great interest. Send me all the cards and all the questions you would like and I will resolve and explain as much as I can. However, I cannot allow my name to appear next to yours on the frontispiece of your catalogue: this would only be possible if we were in daily contact and able to personally discuss all the matters related to this work; there are points regarding the cataloguing of folktales on which the greatest specialists do not agree. I would have to check all of your work, which is impossible. But you can certainly mention and specify my collaboration in the prologue. ${ }^{49}$

In his letter dated 23 October 1957, Anderson continues to express his willingness to help Amades with his cataloguing. He tells him once again that he will check the cataloguing of Amades's folktales published in the journal Schweizeriches Archiv für Volkskunde (Anderson 1954) so that Amades can use it in his catalogue. He also expresses his conviction that it will not be difficult 
to find a publisher for a catalogue that is "so desired by specialists", and says that he will do everything possible to help Amades. Finally he concludes that the preparation of the new edition of the Aarne-Thompson catalogue will still require many months of work.

On 4 December 1957, Anderson writes to Amades to tell him that he has received the three letters and the precious parcel of books, and that he is profoundly grateful for them. He then asks Amades to excuse his delay in responding to him and explains that it is because he wanted to include some of the classifications that he had promised Amades in his reply. He says that he has already classified the tales that Amades had sent him earlier and that he will attach the notes to the folktales of Serra i Boldú.

Anderson is as good as his word because in his next letter, dated 16 December 1957, he sends Amades his classification of the eighteen volumes of Rondalles populars (Serra i Boldú 1930-1933) and the volume Rondalles meravelloses (Serra i Boldú 1924). In this letter, Anderson advises Amades on a system to follow when preparing the catalogue. He says that the most useful system is the one used by Delarue, which requires an analysis of every version of each type, but he says that this system requires an enormous amount of work and would delay the publication of the book. He therefore advises Amades to restrict himself to making brief summaries of each type, as in the Aarne-Thompson catalogue (1928), but without including any lengthy analyses. We must therefore assume Anderson's recommendation for each type is a representative summary of all the versions rather than a detailed analysis based on sequences and motifs.

On this point, it is interesting to note that Anderson's recommendation mirrors the criterion used in the latest revision of the international catalogue (Uther 2004); that is, the use of a general overview for each type rather than a detailed description of sequences and motifs. This criterion has also been followed in the Catalan catalogues by Oriol and Pujol (2003, 2008).

Anderson then warns him that if only one version of a folktale is known, it is doubtful whether it should be catalogued. According to Anderson, "it is very often a combination of traditional (or non-traditional) motifs, a free composition by a narrator (a compiler or editor)" ${ }^{50}$

This fruitful collaboration continues in the following letters. Amades sends Catalan folktales to Anderson, who then catalogues them and in return gives Amades some advice on cataloguing (see Figure 13). For example, in the letter dated 30 January 1958, he recommends that Amades reserve space in his catalogue for fables, provided that these stories really exist in the Catalan oral tradition. To reinforce this criterion, he says that Aarne and Thompson included many of Aesop's fables in their catalogue, and as examples, cites types 34,41 , $50,51,57,60,61,62$, and 70 , among others. 
[Pau Bertrian y Bros], Les rondalles potu-
lars catalunes ilustrades for En foon Vida. I. II. Barcelond 1908.1909.

- I p.1-16 [nv.I], El fill de l's". Autra 301B.

- Ifr. 1T-32 [ur. II]" Les tres filles del rey". AaTh 9568 .

- In.33-44[nn. III] "El nen y lar rena més bonichs que'l sot que'ns enllumena". Atath 70\%

$x$ Ip.45-48[m. IV], "El ruech de les buicees" Lha légencle de l'honme transformé en âne que j'ai étudiée.

- Ifr. 49-64 [nn . VI, \&ls tres frectudents". Aath $654+655$.

- If. 65-72 [m. 17 I" El gat del gegant". Atash $311+665 I$.

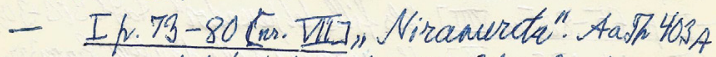
(t mu motif du type tarth 408: "\&l sol y la serene fa tornar la gent morend").

- If 81-86 [m. DIII]. El hríncep serfent". thatr $480+433+425$ (selor Swatn: 425 B).

Figure 13. First page of Walter Anderson's catalogue of the Les rondalles populars catalanes by Pau Bertran i Bros, annex to the letter from Walter Anderson to Joan Amades, dated 30 October 1958. Fons Amades: Centre de Documentació de Cultura Popular de la Generalitat de Catalunya, Barcelona.

\section{THE CATALOGUE OF ETIOLOGICAL LEGENDS}

The process of cataloguing Catalan folktales and Anderson's guidance with regard to the materials that needed to be included made it clear to Amades that he should also publish a catalogue of etiological legends, and once again Anderson acted as a mentor to Amades.

In his letter dated 12 September 1957, Anderson explains to Amades that most national catalogues of etiological and historical legends have been published in the appendices to various folktale catalogues. These include the ones by Aarne (1918, 1920), Qvigstad (1925), Loorits (1926), and Sinninghe (1943), 
and for the German legends about giants, the catalogue by Höttges (1937). In his next letter dated 21 September 1957, he recommends the system used by Loorits (1926) for etiological legends, although he says that those used by Sinninghe (1943) and Aarne (1918, 1920) are also highly recommendable. He then continues that, to assist Amades, he has translated the titles of the first 59 types by Loorits into French, as well as the abbreviated titles of types 60 to 127. Anderson includes these lists in an appendix to the letter.

Amades must have been considering publishing the catalogue in French, as in his letter dated 23 October 1957, Anderson says:

When talking about animals, plants, etc., you should use the French nomenclature; if they are unusual and special terms that do not appear in the dictionary, you can use the Catalan word, followed in brackets by 'a type of...' Latin scientific names are useful, but not essential. ${ }^{51}$

Amades was probably considering publishing the catalogue of etiological legends as a separate book from the catalogue of folktales, because in his letter dated 11 April 1958, Anderson says that etiological and religious legends and tales about treasures should be catalogued, but that it is quite a difficult task and that a catalogue of that type could be published together with the catalogue of folktales, like those by Loorits (1926) and Sinninghe (1943), or as part of a separate book.

\section{EPILOGUE}

The task of cataloguing Catalan folktales was interrupted by the death of Amades in 1959. Anderson tried to continue the work and even raised the subject at the conference held in Kiel-Copenhagen in 1959. That conference discussed a proposal by Anderson to preserve the work done and ensure the completion of the catalogue. However, despite general support for the proposal, the difficulty of accessing Amades's materials and the fact that Anderson died three years later meant that the project was never completed (Oriol 1999: 383-384). Consequently, Stith Thompson's revision of the international catalogue published in 1961 was therefore only able to include Anderson's cataloguing (1954) of the Catalan folktales contained in the volume Folklore de Catalunya: Rondallistica (Amades 1950).

Fortunately, the last thirty years have seen renewed interest in the cataloguing of Catalan folktales. Josep Antoni Grimalt (1975) studied and catalogued the Majorcan folktales collected by Antoni M. Alcover, and Josep M. Pujol (1982) did the same for the other collections of Catalan folktales that had been published 
up to the end of the 1970s. Both studies were conducted in accordance with the guidelines of the second revision of the Aarne-Thompson catalogue (1961).

In 2000, Carme Oriol and Josep M. Pujol undertook the project of cataloguing all the Catalan folktales. To date, the most important results of the project have been: the Índex tipològic de la rondalla catalana (Oriol \& Pujol 2003), which is cited in the latest revision of the international catalogue, The Types of International Folktales (Uther 2004); the Index of Catalan Folktales (Oriol $\&$ Pujol 2008), a revised and expanded version of the previous catalogue, published in English and adapted to changes in the latest revision of the international catalogue (Uther 2004); and the multilingual website RondCat (http://rondcat.arxiudefolklore.cat/), which enables data on Catalan folktales to be constantly updated. As a result, the cataloguing of Catalan folktales, in which Amades and Anderson were key figures in the 1950s, has finally come to fruition and been presented to the international research community, just as the two folklorists would have wished.

\section{CONCLUSIONS}

The letters sent to Joan Amades by Walter Anderson provide us with first-hand knowledge of interesting aspects regarding the history of folklore because they cover topics that are related to the life and works of both folklorists.

The letters show that they collaborated to a remarkable degree. Amades provided Anderson with Catalan versions of folktales that he was able to use in his comparative studies. For his part, Anderson rated very highly the abundant corpus of Catalan folktales, and especially the book Folklore de Catalunya: Rondallística (Amades 1950).

The letters also enable us to follow how the cataloguing of Catalan folktales has evolved over the years, and to see the crucial role played by Anderson early on in the process. Anderson advised his Catalan colleague on how to determine what constituted a folktale, what criteria should be adopted when cataloguing, how to create international indices, how to approach the cataloguing of folktales, and how to deal with legends. Moreover, Anderson himself also undertook a thorough cataloguing of the Catalan folktales collections available to him, from Folklore de Catalunya: Rondallistica (Amades 1950) to those sent to him by Amades.

In addition, the letters provide other details relating to the publications that were exchanged by the two folklorists, the working materials they sent each other, their intention to participate in international conferences where they would have met, etc. In summary, the letters reflect the extensive collaboration 
between two exceptional folklorists who both possessed a remarkable capacity for work and who established a personal and professional relationship based on mutual respect and admiration.

\section{ACKNOWLEDGEMENTS}

This study is part of the research by the Grup de Recerca Identitats en la Literatura Catalana (GRILC), established by the Catalan Government (2014 SGR755) and was conducted as part of a project on Catalan folk literature, which received funding from the Spanish Government's Ministry of Economy and Competitiveness (FFI 2012-31808).

\section{NOTES}

1 For more biographical information on Anderson, see Järv (2008), Levin (1963), Ranke (1962, 1977), Seljamaa (2005), and Thompson (1996: 261, 333).

2 On the biographical details of Amades, see Calvo (1990) and Oriol (2008).

3 I am very grateful for the help provided by Veronica Guarch, Antoni Serés, and Marcus Yáñez when consulting the archives of Joan Amades.

4 Some years ago, I conducted a thorough investigation in an attempt to locate the letters that Amades wrote to Anderson. After finding that they were not in Barcelona with the rest of Amades's correspondence, I subsequently contacted Anderson's family, with the help of Professor of Romance Philology at the University of Kiel, Phil Helmut Lüdtke, and was informed that they did not have them either. In a letter written from Brühl on 7 April 1998, Mrs Helene Anderson told me that this correspondence had not been preserved because she had passed on all Anderson's documentation to the folklorist Kurt Ranke, who had been Anderson's disciple and a lecturer at the University of Kiel. Finally, I was also unable, despite the help of Hans-Jörg Uther, to find the letters in the archives of the Enzyklöpadie des Märchens (Göttingen, Germany), which houses the Kurt Ranke archives. Although my efforts to locate Amades's correspondence were ultimately unsuccessful, I am nevertheless very grateful to all of these individuals for their assistance and for the efforts they made on my behalf at that time.

5 Throughout this paper, I have given English translations for the excerpts from the letters in the text, and supplied the original French in the endnotes. The originals of the letters can be consulted in Oriol (2014).

${ }^{6}$ On Walter Anderson and the historic-geographic method, see Chesnutt (1996).

7 Je comprends le catalan et l'espagnol, mais je ne connais pas ces deux langues assez bien pour en faire usage dans mes lettres.

8 Letter dated 18 January 1953. 
9 Letter dated 7 August 1957, to which Anderson attaches 18 pages containing the catalogue of the folktales in the first fifteen volumes of the Alcover collection (1936-1972).

${ }^{10}$ Amades (1950, No. 93: 229-231).

${ }^{11}$ Amades (1950, No. 173: 416-420).

12 This folktale has no catalogue number in the international type index (Uther 2004). C-011 is the internal number given on the RondCat website for those types found during the cataloguing of Catalan folktales that are not included in the international catalogue.

${ }^{13}$ Clatell, derived from the older clotell, is probably a diminutive of clot (hole), as applied to the small cavity at the occiput (Coromines 1986: 741-743). The origin of the word clot is obscure, and is probably pre-Roman (ibid.: 765).

${ }^{14}$ Quant aux trois ouvrages que vous désirez voir, je ne puis vous en envoyer mes propres exemplaires, car ceux-ci ont été anéanti (ainsi que tous mes livres et tous mes manuscrits) pendant le siège de Koenigsberg (1945); pourtant vous recevrez bientôt ces trois livres de la part du commissionnaire de l'Académie des Sciences de Finlande, et je vous prie de les accepter comme témoignage de ma reconnaissance.

${ }^{15}$ La Fédération des Folkloristes qui vous intéresse est une organisation bien étrange: une organisation sans président, sans commissions, sans filiales, sans budget, sans séances, sans procès-verbaux, sans comptes-rendus.

${ }^{16}$ La Fédération est quelque chose comme la "république des savants" imaginée par Erasme de Rotterdam: on en devient membre en déclarant (ou même en montrant) qu'on est prêt à aider les autres folkloristes dans leurs études - et maintenant vous en êtes membre au même titre que moi. Si quelque folkloriste a besoin de matériaux folkloriques catalans, je lui donnerai votre adresse - de même que je l'ai reçue de la part de M. Paul Delarue. Et si vous-même vous aurez besoin de quelques matériaux, de renseignements bibliographiques etc., moi et tous les autres folkloristes, nous serons heureux de pouvoir vous servir à cet égard. C'est tout; il n'y a pas de formalités, il n'y a pas de listes de membres. - Moi-même, je suis membre du comité de rédaction des FF Communications (le seul comité de la Fédération!), c'est-à-dire de la série éditée au nom de la Fédération des Folkloristes et financée par l'Académie Finnoise des Sciences; depuis 1926 mon nom, à côté de cinq autres noms, figure sur les couvertures de tous les volumes de cette série (il y en a déjà 60, formés par 144 numéros); et cependant ni moi ni mes cinq collègues (parmi lesquels le prof. Martti Haavio est le chef) ne possédons aucun document qui atteste notre qualité de rédacteurs (ou même de membres de la Fédération)!.

${ }^{17}$ Consol Mallofrè made clear her interest in stamp collecting to Antoni Serés during a visit he made to her home. I thank Antoni Serés for providing me with this information.

18 This congress is also cited on the website of the Joan Amades Association (http:// joanamades.cat/la-postguerra-la-internacionalitat-i-les-grans-obres-1940-1959/, last accessed on September 18, 2015).

${ }^{19}$ A la fin du mois de juin j'espère de vous faire une visite à Barcelone. C'est que j'ai l'intention de me rendre à un congrès qui aura lieu à Porto du 18 au 23 juin (Coló- 
quio de estudos etnográficos "Dr. José Leite de Vasconcelos"). J’y irai (si la situation politique le permettra) via Irún, mais en retournant je passerai par Barcelone, où j’ai l'intention de m'arrêter pour un ou deux jours.

${ }^{20}$ Seljamaa (2005: 159) says that Anderson may have begun work on the monograph when he was a lecturer at Königsberg (between 1940 and 1945).

21 (1) Est-ce que le géant tient les yeux ouverts en dormant (et fermés en veillant), ou non? (2) Est-ce que la vieille sorcière enfonce l'aiguille enchantée dans une oreille de la fille, ou dans un autre endroit de sa tête? (3) Est-ce que la fille est métamorphosée en colombe, ou en un autre oiseau? (4) Est-ce que la sorcière promet au prince de devenir belle de nouveau, ou non? (5) Est-ce que l'oiseau vient trois fois dans le jardin du prince pour parler au jardinier, ou non? (6) Si c'est ainsi: quelles sont les paroles de l'oiseau et du jardinier?

${ }^{22}$ The Engravings and Images Department of the Museu d'Indústries i Arts Populars at the Poble Espanyol, of which Amades was the director, was housed in the building of the Arxiu Històric Municipal de Barcelona. The unpublished versions sent by Amades must have come from this archive.

${ }^{23}$ This manuscript has been of great assistance to researchers carrying out subsequent studies of the folktale The Three Oranges, for example Goldberg (1997) and Shojaei Kawan (2000 and 2002).

${ }^{24}$ Les organisations nordiques des folkloristes dont vous parlez ne sont pas des sociétés spéciales: ce sont des archives où tous les matériaux folkloriques d'une nation (imprimés ou manuscrits) sont recueillis et conservés. Il y a de telles archives à Copenhague, à Oslo, en plusieurs endroits de la Suède, à Helsinki, à Tartu, à Riga. En Allemagne on peut mentionner les archives des chansons populaires à Fribourg et des contes populaires à Marbourg. Même la grande "Fédération des Folkloristes" internationale n'est pas une vraie société concrète: c'est plutôt une ligue idéale de tous les folkloristes du monde qui se sont promis de s'entr'aider dans leurs études.

${ }^{25}$ La connaissance de votre belle langue est malheureusement trop peu répandue dans le monde.

${ }^{26}$ On the subject matter covered by Anderson in his paper, see Oring (1984).

${ }^{27} \mathrm{Il}$ y a plus de trente ans, j'avais établi la thèse que chaque homme qui récite un conte populaire l'a entendu lui-même non pas une seule fois dans sa vie, mais presque toujours plusieurs fois et de la bouche de plusieurs personnages; autrement le conte s'altérerait et se déformerait de plus en plus, ainsi que bientôt il ne serait plus à reconnaître.

${ }^{28}$ Cette thèse fut combattue par beaucoup de folkloristes, qui ne voulaient pas y croire.

${ }^{29}$ Pour décider la question, je lus une légende (peu connue) à trois étudiants de notre université, en les priant de l'écrire le jour suivant ainsi comme ils s'en souviendraient alors, et de la lire chacun à un autre étudiant, qui un jour après ferait la même chose; et ainsi de suite douze fois. En résultat j'eus trois séries, de 12 textes chacune, et les derniers textes de ces séries (A12, B12, C12) étaient tous affreusement déformés et divergeaient entre eux complètement; c'était précisément ce que j’avais prévu. Il y a une vingtaine d'années, j'avais fait quelques expériences analogues en Estonie (sans en publier les résultats); les résultats avaient été absolument identiques. 
${ }^{30}$ It is unclear whether Amades sent him this first edition (Amades 1948-49) or the second, which was also published in two volumes in 1953.

${ }^{31}$ Letter dated 18 January 1953.

${ }^{32}$ Letter dated 11 February 1954.

${ }^{33}$ Letter dated 11 February 1954.

${ }^{34} \mathrm{La}$ lecture de votre grand livre me fournit beaucoup de surprises. En lisant le conte $\mathrm{N}^{\circ} 231$ "L'home tornat ruc", je fis vraiment "des yeux comme des oranges": c'est un conte répandu en Allemagne depuis la Guerre des Trente Ans (parmi ses versions, il y en a deux du XVIIe siècle), un conte qui est probablement emprunté au roman d'Apulée, et que je connaissais très bien, puisque je l'avais étudié il y a plus de quarante ans! Mais je n'avais pas la moindre idée que ce conte fût connu aussi chez d'autres peuples - et surtout chez les Catalans!

${ }^{35}$ Letter dated 4 April 1953.

36 Je suis bien étonné de lire que vous avez recueilli tant de contes et de chansons populaires: 15.000 - c'est un nombre colossal!

${ }^{37} \mathrm{Si}$ un spécialiste se met à y chercher des versions d'un certain conte populaire - comment les pêchera-t-il de l'océan du livre catalan? Des versions d'un même conte s'y trouvent souvent dispersés en différents lieux - par exemple de véritables contes de fées (grâce à une localisation accidentelle) dans le chapitre des légendes de châteaux. Est-ce que le spécialiste doit imiter mon exemple en sacrifiant plusieurs semaines à l'étude du livre catalan? Ce n'est pas une chose que chacun puisse faire! Pour remédier, au moins en partie, à ce mal, j'indique dans la table suivante les numéros, sous lesquels le lecteur trouvera les contes-types registrés par Aarne et Thompson.

${ }^{38}$ Quant à la définition de ce qui est un conte populaire, je confesse de me soucier assez peu de définitions et classifications - en tout cas moins que vous qui êtes un compatriote de Raymond Lulle. Dans l'univers il y a tant de choses qui résistent à une définition rigoureuse, tant de formes de transition ou hybrides qui ne peuvent être classées. Moi j'appellerais un "conte" tout récit de ce qui s'est passé une fois, mais non pas de ce qui se passe beaucoup de fois à présent. Bien des peuples sauvages croient que pendant chaque éclipse le soleil ou la lune sont dévorés par un monstre et sortent puis de son ventre: ce n'est pas un conte, c'est une croyance. Le peuple russe dit que la terre repose sur trois baleines gigantesques, dont les convulsions causent les tremblements de terre: cela aussi, c'est une croyance, ce n'est pas un conte. Mais il y a aussi des peuples qui croient qu'au temps jadis il y a eu au ciel dix soleils qui brûlaient la terre sans pitié, jusqu'à ce qu'un héros en tua neuf par ses flèches: ceci, c'est un conte véritable - un conte étiologique.

Il y a des contes qui expliquent l'origine d'un proverbe ou d'une devinette, ou bien d'un surnom moqueur: tout cela, ce sont toujours des contes; mais par exemple les jeux de doigts ne le sont pas: ce sont plutôt de petits drames que de contes. Je ne classerais pas parmi les contes non plus les problèmes mathématiques (par exemple celui des 100 oies: $x+x+1 / 2 x+1 / 4 x+l=100$ ), ni les textes que vous appelez "embarrassallengues".

${ }^{39} \mathrm{Je}$ ferai tout mon possible pour vous le procurer dans quelques semaines. 
${ }^{40}$ Vous avez raison: la composition d'un catalogue national de contes populaires est un travail extrêmement utile, mais aussi très grand et très difficile.

Il faut enregistrer, si c'est possible, tous les contes populaires, bien qu'ils aient été publiés dans des almanachs, des revues, des journaux etc., et même ceux qui sont restés non-publiés; aussi ceux qui furent imprimés dans des livres d'enfants, pourvu que ce ne soient pas des remaniements artificiels de textes déjà enregistrés dans votre catalogue.

Pourtant il ne faut pas tenir compte des légendes locales sur les fées, les géants, les sirènes etc., sur les pays et les vaisseaux fabuleux, ni des légendes sur les vies des saints ou sur des miracles religieux. Ce sont là des choses très intéressantes, mais qui exigent un catalogue spécial.

Quant aux anecdotes et facécies, il faut en enregistrer le plus grand nombre possible - au moins toutes celles qui sont nommées dans le catalogue d'Aarne et Thompson. Pourtant les anecdotes purement locales (sur le blason populaire, etc.) pourraient être omises, de même que les interprétations du chant des oiseaux et les problèmes mathématiques.

${ }^{41}$ En lisant votre grand recueil, je n'ai point enregistré tous vos contes, mais seulement ceux qui figurent dans le catalogue d'Aarne et Thompson, et ceux qui y manquent, mais sont d'ailleurs très connus et importants. Tout ceci j'ai imprimé dans mon compterendu.

Anderson's review (1954).

${ }^{42} \mathrm{Si}$ vous avez des doutes sur quelque conte populaire, envoyez-m’en un bref résumé ou bien le numéro correspondant de votre Rondallística, et je vous en dirai mon opinion.

${ }^{43}$ En général, je ferai tout mon possible pour vous secourir dans votre entreprise.

${ }^{44}$ On the early work to catalogue the Alcover folktales, see Oriol (2001).

${ }^{45}$ On the steps that Amades took to obtain the materials that needed cataloguing, see Oriol (1998, 1999, 2001, and 2012).

${ }^{46}$ Vous me priez de vous expliquer bien clairement, quels contes sont exclus du système d'Aarne-Thompson. Hélas! C'est presque impossible; il faudrait un nouveau Raymond Lulle pour vous fournir toutes les définitions, distinctions et classifications que vous désirez. On peut seulement dire en général que les légendes religieuses, bibliques, étiologiques, historiques et locales sont exclues de ce système-là; pour tous les contes de ces genres on compose des catalogues à part.

${ }^{47}$ Pour faciliter votre travail, j'ai l'intention de faire une révision de votre Rondallística pour compléter l'index que j'en ai publié dans les Archives suisses des traditions populaires.

48 J'attends avec grand intérêt les recueils de contes catalans que vous avez eu la bonté de m'annoncer.

${ }^{49}$ Quant à vos propositions, je ferai avec le plus grand plaisir tout le possible pour vous aider dans votre entreprise, à laquelle je prends beaucoup d'intérêt. Envoyez-moi toutes les fiches et toutes les questions que vous voulez, et j'arrangerai et j'expliquerai tout ce que je pourrai. Pourtant je ne puis consentir à ce que mon nom apparaisse à côté du vôtre sur le frontispice de votre catalogue: ce serait possible seulement si nous pouvions entretenir un contact quotidien et conférer personnellement sur toutes les 
questions qui s'élèvent pendant un tel travail; quant à la classification des contes populaires, il y a des points à l'égard desquels les plus grands spécialistes ne sont pas d'accord l'un avec l'autre. Je devrais donc contrôler tout votre travail, ce qui est impossible. - Mais vous pouvez, sans doute, mentionner et préciser ma collaboration dans la préface de votre livre.

${ }^{50}$ C'est trop souvent une combinaison accidentelle de motifs traditionnels (ou non-traditionnels), une libre composition de quelque conteur (ou même de quelque collectionneur ou éditeur).

${ }^{51}$ En parlant des animaux, des plantes, etc., vous devriez faire usage de la nomenclature française; s'il s'agit de termes rares et spéciaux qui manquent dans les dictionnaires, vous pouvez conserver le nom catalan, en y ajoutant entre deux parenthèses: (une espèce de...). Les noms latins scientifiques sont utiles, mais non pas indispensables.

\section{MANUSCRIPT SOURCES}

Collected letters of Walter Anderson (1953-1958) from the Amades archive (Fons Amades. Centre de Documentació de Cultura Popular de la Generalitat de Catalunya, Barcelona).

\section{REFERENCES}

Aarne, Antti 1918. Estnische Märchen- und Sagenvarianten. FFC 25. Helsinki: Suomalainen Tiedeakatemia.

Aarne, Antti 1920. Finnische Märchenvarianten, Ergänzungsheft I. FFC 33. Helsinki: Suomalainen Tiedeakatemia.

Aarne, Antti \& Thompson, Stith 1928. The Types of the Folktale: A Classification and Bibliography. FFC 74. Helsinki: Suomalainen Tiedeakatemia.

Aarne, Antti \& Thompson, Stith 1961. The Types of the Folktale: A Classification and Bibliography. FFC 184. Helsinki: Suomalainen Tiedeakatemia.

Alcover, Antoni M. 1936-1972. Aplec de Rondaies Mallorquines d'En Jordi des Racó. 24 vols. Ciutat de Mallorca: Moll.

Amades, Joan 1948-1949. Les cent millors rondalles populars. 2 vols. Barcelona: Selecta.

Amades, Joan 1950. Folklore de Catalunya: Rondallística (Rondalles-TradicionsLlegendes). Barcelona: Selecta.

Amades, Joan 1950-1956. Costumari català. 5 vols. Barcelona: Selecta.

Amades, Joan 1951. Folklore de Catalunya: Cançoner (Cançons-Refranys-Endevinalles). Barcelona: Selecta.

Amades, Joan 1957. Contes Catalans. Contes des cinq continents 3. Paris: Erasme.

Anderson, Walter 1923. Kaiser und Abt: Die Geschichte eines Schwanks. FFC 42. Helsinki: Suomalainen Tiedeakatemia.

Anderson, Walter 1925-1926. Die Marspanik in Estland 1921. Zeitschrift des Vereins für Volkskunde, Vol. 35-36, pp. 229-252. 
Anderson, Walter 1937. Kettenbriefe in Estland. Eesti Rahvaluule Arhiivi toimetused 7. Tartu: n.p.

Anderson, Walter 1951. Ein volkskundliches Experiment. FFC 141. Helsinki: Suomalainen Tiedeakatemia.

Anderson, Walter 1954. Eine katalanische Märchensammlung. Schweizeriches Archiv für Volkskunde 50, pp. 57-62. Available at http://retro.seals.ch/digbib/ view2?pid=sav-001:1954:50::63, last accessed on November 19, 2015.

Anderson, Walter 1956. Eine neue Arbeit zur experimentellen Volkskunde. FFC 168. Helsinki: Suomalainen Tiedeakatemia.

Anderson, Walter 1960. Volkserzählungen in Tageszeitungen und Wochenblättern. In: W. D. Hand \& G. O. Arlt (eds.) Humaniora: Essays in Literature, Folklore and Bibliography, Honoring Archer Taylor on his Seventieth Birthday. Locust Valley, N.Y.: J. J. Augustin, pp. 58-68.

Calvo, Lluís 1990. Joan Amades i Gelats, biografia. In: Antoni Anguela \& Lluís Calvo (eds.) El món de Joan Amades. Barcelona: Departament de Cultura de la Generalitat de Catalunya, pp. 111-191.

Chesnutt, Michael 1996. The Great Crusader of Diffusionism: Walter Anderson and the Geographic-Historical Method. In: Ülo Valk (ed.) Studies in Folklore and Popular Religion, Vol. 1. Papers Delivered at the Symposium "Walter Anderson and Folklore Studies Today". Tartu: University of Tartu, pp. 11-26.

Coromines, Joan 1986 [1981]. Diccionari etimològic $i$ complementari de la llengua catalana, Vol. 2. Barcelona: Curial.

Goldberg, Christine 1977. The Tale of the Three Oranges. FFC 263. Helsinki: Suomalainen Tiedeakatemia.

Grimalt, Josep A. 1975. Classificació de les rondalles de Mossèn Alcover: Introducció a llur estudi. Doctoral thesis. Barcelona: Universitat de Barcelona.

Höttges, Valerie 1937. Typenverzeichnis der deutschen Reisen- und riesischen Teufelssagen. FFC 122. Helsinki: Suomalainen Tiedeakatemia.

Järv, Risto 2008. Anderson, Walter (1885-1962). In: Donald Haase (ed.) The Greenwood Encyclopedia of Folktales and Fairy Tales, Vol. 1. Westport: Greenwood Press, pp. 38-39.

Kalmre, Eda 2013. The Human Sausage Factory: A Study of Post-War Rumour in Tartu. Amsterdam \& New York: Editions Rodopi B.V.

Krohn, Kaarle 1910. Statuten des Bundes "FF". Erster Bericht über die Tätigkeit des folkloristischen Forscherbundes "FF". FFC 4. Helsinki: Suomalaisen Tiedeakatemian Toimituksia, pp. 15-16.

Levin, Isidor 1963. Walter Anderson. Deutsches Jahrbuch für Volkskunde, Vol 9. Berlin: Akademie Verlag, pp. 293-311. Available at http://digi-alt.ub.hu-berlin.de/viewer/ image/DE-11-001911673/307/, last accessed on September 21, 2015.

Loorits, Oskar 1926. Livische Märchen- und Sagenvarianten. FFC 66. Helsinki: Suomalainen Tiedeakatemia.

Oring, Elliott 1984. Experimentelle Erzählforschung. Enzyklopädie des Märchens, Vol. 4. Berlin: Walter de Gruyter, pp. 684-694.

Oriol, Carme 1990. Revision of Amades' Classification of the Catalan Folktales. Fabula, Vol. 31, Nos. 3-4, pp. 304-312. DOI: 10.1515/fabl.1990.31.3-4.304. 
Oriol, Carme 1998. Els rondallaris mallorquins, menorquins i eivissencs de l'Enzyklopädie des Märchens. Estudis de llengua i literatura en honor de Joan Veny, Vol. 2. Barcelona: Publicacions de l'Abadia de Montserrat, pp. 463-479.

Oriol, Carme 1999. El projecte de catalogació de la rondallística catalana en els anys 50. Actes de l'Onzè Col-loqui Internacional de Llengua i Literatura Catalanes. Palma (Mallorca), 8-12 de setembre de 1997. Barcelona: Publicacions de l'Abadia de Montserrat, pp. 365-386.

Oriol, Carme 2001. Els primers treballs catalogràfics de les Rondaies Mallorquines d'en Jordi des Recó. Estudis de llengua i literatura catalanes, Vol. 43. Miscel-lània Giuseppe Tavani 2. Barcelona: Publicacions de l'Abadia de Montserrat, pp. 185-201.

Oriol, Carme 2008. Amades, Joan (1890-1959). In: Donald Haase (ed.) The Greenwood Encyclopedia of Folktales \& Fairy Tales, Vol. 1. Westport: Greenwood Press, pp. 29-30.

Oriol, Carme 2012. Les primeres rondalles d'Enric Valor i la seva catalogació tipològica inèdita. Estudis de llengua i literatura catalanes, Vol. 65. Miscel-lània Albert Hauf 4. Barcelona: Publicacions de l'Abadia de Montserrat, pp. 201-213.

Oriol, Carme 2014. Édition de la correspondance entre les folkloristes Walter Anderson et Joan Amades. Estudis de Literatura Oral Popular / Studies in Oral Folk Literature, No. 3, pp. 49-84. DOI: http://dx.doi.org/10.17345/elop201449-84.

Oriol, Carme \& Pujol, Josep M. 2003. Índex tipològic de la rondalla catalana. Barcelona: Generalitat de Catalunya, Departament de Cultura.

Oriol, Carme \& Pujol, Josep M. 2008. Index of Catalan Folktales. FFC 294. Helsinki: Suomalainen Tiedeakatemia.

Pujol, Josep M. 1982. Contribució a l'índex de tipus de la rondalla catalana. Degree dissertation. Barcelona: Universitat de Barcelona.

Qvigstad, Just 1925. Lappische Märchen- und Sagenvarianten. FFC 60. Helsinki: Suomalainen Tiedeakatemia.

Ranke, Kurt 1962. Walter Anderson (1885-1962). Fabula, Vol. 5, unpaginated betw. 184-185.

Ranke, Kurt 1977. Anderson, Walter. Enzyklopädie des Märchens, Vol. 1. Berlin: Walter de Gruyter, pp. 493-494.

RondCat. Cercador de la rondalla catalana / Catalan Folktales Search Engine / Buscador del cuento folclórico catalán / Moteur de recherche des contes populaires catalans. Available at www.rondcat.arxiudefolklore.cat, last accessed on September 21, 2015.

Seljamaa, Elo-Hanna 2005. Walter Anderson: A Scientist beyond Historic and Geographic Borders. In: Kristin Kuutma \& Tiiu Jaago (eds.) Studies in Estonian Folkloristics and Ethnology: A Reader and Reflexive History. Tartu: Tartu University Press, pp. 153-168.

Serra i Boldú, Valeri 1924. Rondalles meravelloses. Barcelona: Editorial Catalana.

Serra i Boldú, Valeri 1930-1933. Rondalles populars. 18 vols. Barcelona: Políglota.

Shojaei Kawan, Christine 2000. Einige Gedanken zur internationalen Märchenforschung, anhand von drei Orangen. Volkskunde in Niedersachsen, Vol. 17, No. 1, pp. 41-54.

Shojaei Kawan, Christine 2002. Orangen: Die drei O. (AaTh 408). Enzyklopädie des Märchens, Band 10, pp. 346-355. Berlin: Walter de Gruyter. 
Sinninghe, Jacques R. W. 1943. Katalog der niederländischen Märchen-, Ursprungssagen-, Sagen- und Legendenvarianten. FFC 132. Helsinki: Suomalainen Tiedeakatemia.

Thompson, Stith 1932-1936. Motif-Index of Folk Literature. 6 vols. Bloomington: Indiana University Press.

Thompson, Stith 1996. A Folklorist's Progress: Reflections of a Scholar's Life. Edited by J. H. MacDowell \& I. G. Carpenter \& D. Braid \& E. Peterson-Veatch. Special Publications of the Folklore Institute, No. 5. Bloomington: Indiana University.

Uther, Hans-Jörg 2004. The Types of International Folktales: A Classification and Biography. FFC 284-286. Helsinki: Suomalainen Tiedeakatemia. 